\title{
INITIAL CLINICAL EXPERIENCE WITH TISSUE PLASMINOGEN ACTIVATOR (tPA) ASSISTED REMOVAL OF SUBMACULAR HAEMORRHAGE
}

\author{
ANTHONY P. MORIARTY ${ }^{1}$, IAN L. McALLISTER ${ }^{2}$ and IAN J. CONSTABLE ${ }^{2}$ \\ Liverpool and Perth, Australia
}

\begin{abstract}
SUMMARY
Tissue plasminogen activator (tPA) $(250 \mu \mathrm{g} / \mathrm{ml})$ was used to facilitate removal of submacular thrombus in $\mathbf{1 5}$ patients. Following a three-port vitrectomy and subretinal tPA injection $(0.1 \mathrm{ml})$ via a 30 gauge needle, blood was evacuated after enzymatic dissolution for 20 minutes. Two injections were required in some cases. Nine women and six men were treated (mean age 75.5 $\pm \mathbf{8 . 6}$ years). Duration of symptoms ranged from 2 days to 8 weeks. One case was due to a retinal macroaneurysm, the others to age-related macular degeneration. Vision improved in 13 patients and remained the same or deteriorated in 2 (mean follow-up 11, \pm 4.9 months). Well-defined subretinal neovascular membranes were identified in 2 patients and occult neovascularisation suspected in 2 others. A cataract developed in 1 case and retinal detachments in 2 others; all were treated successfully. The poor visual prognosis associated with submacular haemorrhage may be obviated by the use of the technique we describe.
\end{abstract}

Massive subretinal haemorrhage may cause acute visual loss in age-related macular degeneration (AMD) and is associated with a poor visual prognosis. ${ }^{1}$ Degeneration of the outer retina occurs due to the presence of subretinal clot and blood. ${ }^{2}$ Consequently surgical approaches to remove these clots early in the course of their development have been attempted. Unfortunately, the large retinotomies required to grasp the clot resulted in a high rate of retinal detachment and subretinal fibrosis, ${ }^{3}$ and shearing forces as the clot is manipulated surgically or retracts may damage photoreceptors. ${ }^{4}$ In addition, surgical removal of an undissolved clot is more likely to be complicated by removal of the retinal pigment epithelium (RPE), especially when a

From: ${ }^{1}$ St Paul's Eye Unit, Royal Liverpool University Hospital, Prescot Street, Liverpool, UK; ${ }^{2}$ Royal Perth Hospital, Perth, Western Australia 6014.

Correspondence to: $\operatorname{Dr}$ A. P. Moriarty, Royal Liverpool University Hospital, Prescot Street, Liverpool L7 8XP, UK. tear of the RPE has promoted a haemorrhage.

There has recently been increasing interest in enzymatically directed dissolution of subretinal thrombus with tissue plasminogen activator (tPA) in an attempt to minimise the mechanical disruption to the retina caused by evacuation. Experimental studies of this technique ${ }^{5-7}$ have been followed by limited reports of its application to humans. ${ }^{8,9} \mathrm{We}$ present our clinical experience with tPA assisted removal of submacular clots in our first 15 cases since we adopted this technique.

\section{MATERIALS AND METHODS}

\section{Inclusion Criteria}

All patients who presented with an acute submacular haemorrhage to the Royal Perth Hospital or Lions Eye Institute were considered for treatment with tPA. We gained ethics committee approval for this treatment in January 1992. Initially only patients with a history suggestive of a recent submacular haemorrhage were considered, but with increasing success with the technique we extended inclusion criteria to those patients with a more prolonged history (up to 8 weeks). Although we assumed that the majority of submacular bleeds would be associated with AMD, we included 1 patient with clinical findings suggestive of a retinal macroaneurysm. All patients received a full explanation of the procedure and its potential risks and benefits. Only patients capable of giving informed consent and willing and available for continued follow-up were included.

\section{Guidelines for Inclusion in Trial}

1. Recent history suggestive of bleed (initially within 1 week but a maximum of 8 weeks in 1 case).

2. Submacular haemorrhages of $>5$ disc diameters and also convex with a tenting elevation of the retina, as judged by biomicroscopy, since these 
have a poorer prognosis than flat haemorrhages if left untreated. ${ }^{1}$

3. A previously good visual acuity, implying little pre-existent macular degeneration, and a current vision of $6 / 60$ or worse.

4. An absence of sub-RPE blood at the fovea.

\section{Preoperative Assessment}

1. Snellen visual acuity of both eyes at 6 metres with spectacle correction.

2. Clinical examination of the macula with a 78 dioptre lens (and indirect biomicroscopy) and of the retinal periphery with a 20 dioptre lens (binocular indirect ophthalmoscope) in both eyes (following dilation of the pupils with $1 \%$ tropicamide and $2.5 \%$ phenylephrine).

3. Colour photographs and fluorescein angiography of both eyes following the clinical examination. This was to attempt identification of any subretinal neovascular membrane or retinal macroaneurysm.

\section{Operative Procedure}

A standard three-port core vitrectomy was performed. If the posterior hyaloid was still attached at the posterior pole it was elevated with the extrusion cannula and removed with the vitrector.

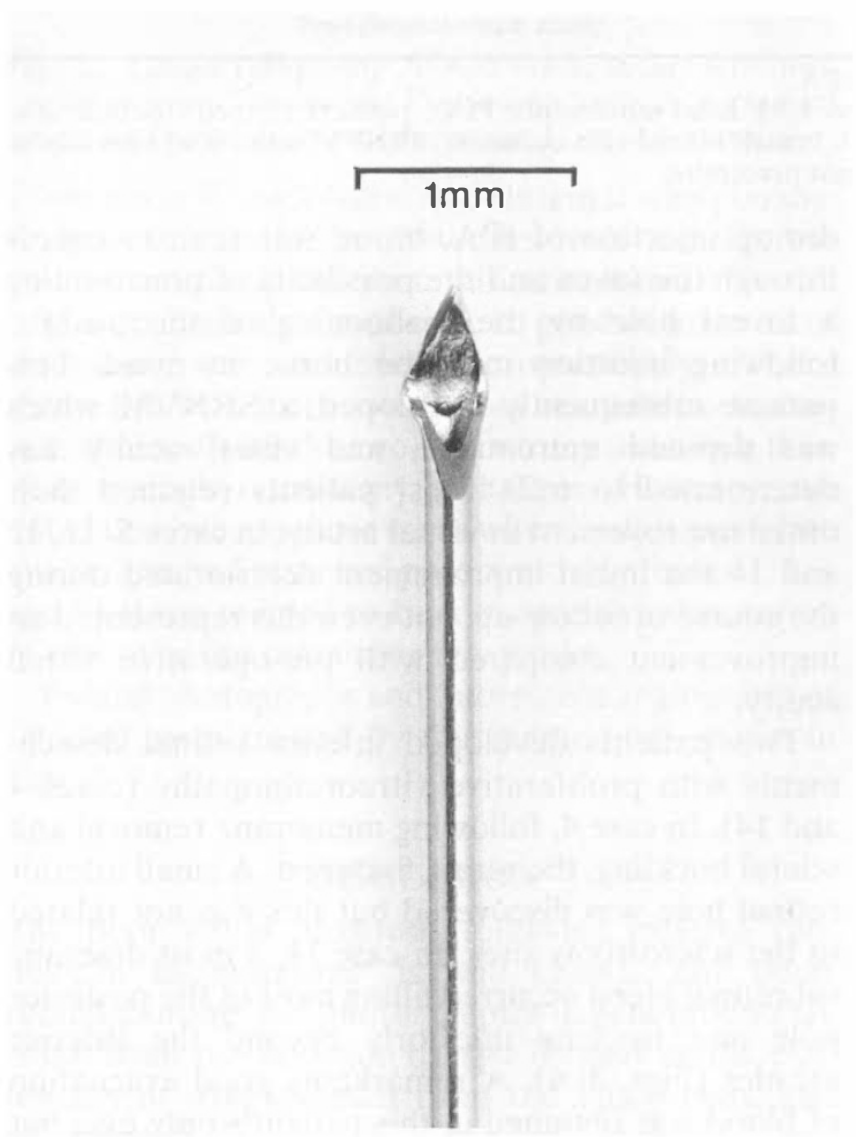

Fig. 1. A 30 gauge needle, 11/2 inches long, used for injection of $t P A$. Note the fine inward bend of the tip towards the bevel.
Tissue plasminogen activator $(250 \mu \mathrm{g} / \mathrm{ml})$ was used, having been stored at $-70{ }^{\circ} \mathrm{C}$ and then reconstituted prior to use. The enzyme was injected via a tuberculin syringe and 30 gauge needle $\left(1 \frac{1}{2}\right.$ inches long) with a fine inward bend of the needle tip towards the bevel (Fig. 1). Injections of $0.1 \mathrm{ml}(25$ $\mu \mathrm{g}$ ) into the clot as temporal to the fovea as possible were performed via a retinotomy produced by just piercing the neurosensory retina with a needle tip and avoiding breaching the RPE.

After allowing enzymatic clot dissolution for 20 minutes, a tapered 20 gauge Charles flute needle was placed just above the retinotomy and the blood aspirated. If only a moderate amount of clot was removed a further $0.1 \mathrm{ml}(25 \mu \mathrm{g})$ injection was performed via the same retinotomy and the previous technique repeated. As much liquefied blood as possible was removed in all cases. In some cases (approximately half) a slightly different technique was adopted. A second retinotomy was made and 15 minutes following the tPA injection balanced salt solution was injected through the needle and irrigated through the substance of the clot, facilitating evacuation of blood and clot fragments via one retinotomy and out through the second.

A gas-fluid exchange was performed with the extrusion needle held just above the retinotomy, greatly facilitating removal of any remaining blood. The retinotomies were then lasered via an endolaser probe. A $20 \%$ mixture of $\mathrm{SF}_{6}$ was then infused to replace the air and tamponade the retinotomies. The sclerostomies and peripheral retina were examined at the conclusion of the procedure and the retina immediately posterior to the sclerostomies was treated with cryotherapy. The patient postured to facilitate closure of the retinotomy with the gasbubble for 3-4 days.

\section{Post-treatment Follow-up}

As soon as possible following evacuation of thrombus a fluorescein angiogram was performed to identify any subretinal neovascular membrane or macroaneurysm (within 1 week in all cases). The patients were reviewed at appropriate intervals as clinical management dictated. A fluorescein angiogram was again performed at 1, 3 and 6 months and, in addition, as clinical developments necessitated.

\section{RESULTS}

The results of this study are shown in Table I. Nine women and 6 men were treated. The mean age of patients in this study was 75.5 ( \pm 8.6 years; range 5586 years). No patient was taking warfarin but 3 were using one aspirin daily. Eight patients were hypertensive, controlled on medication. The majority of procedures were for AMD but we treated 1 patient with a retinal macroaneurysm with good success. 
Table I. Summary of cases

\begin{tabular}{|c|c|c|c|c|c|c|c|c|c|}
\hline $\begin{array}{l}\text { Case } \\
\text { no. }\end{array}$ & Eye & $\begin{array}{c}\text { Age } \\
\text { (years) }\end{array}$ & Pathology & $\begin{array}{l}\text { Pre-op. } \\
\text { VA }\end{array}$ & $\begin{array}{l}\text { Duration of } \\
\text { symptoms }\end{array}$ & $\begin{array}{l}\text { Follow-up } \\
\text { (months) }\end{array}$ & $\begin{array}{l}\text { Best } \\
\text { VA }\end{array}$ & $\begin{array}{l}\text { Current } \\
\text { VA }\end{array}$ & Comments \\
\hline 1 & $\begin{array}{l}\text { OS } \\
\text { OD }\end{array}$ & 84 & $\begin{array}{l}\text { AMD } \\
\text { AMD }\end{array}$ & $\begin{array}{l}\mathrm{HM} \\
6 / 12\end{array}$ & 5 days & $12 / 12$ & $6 / 36$ & $6 / 36$ & \\
\hline 2 & $\begin{array}{l}\text { OS } \\
\text { OD }\end{array}$ & 73 & $\begin{array}{l}\text { AMD } \\
\text { AMD }\end{array}$ & $\underset{6 / 9}{\mathrm{HM}}$ & 5 days & $12 / 12$ & $6 / 36$ & $6 / 36$ & \\
\hline 3 & $\begin{array}{l}\text { OS } \\
\text { OD }\end{array}$ & 86 & $\begin{array}{l}\text { AMD } \\
\text { AMD }\end{array}$ & $\begin{array}{l}1 / 60 \\
6 / 12\end{array}$ & 5 days & $12 / 12$ & $6 / 24$ & $6 / 24$ & PED noted post-operatively \\
\hline 4 & $\begin{array}{l}\text { OS } \\
\text { OD }\end{array}$ & 66 & $\begin{array}{l}\text { AMD } \\
\text { AMD }\end{array}$ & $\begin{array}{c}5 / 60 \\
6 / 6\end{array}$ & 3 days & $6 / 12$ & $6 / 18$ & $6 / 18$ & $\begin{array}{l}\text { Inf. RD + PVR. Flattened } \\
\text { surgically }\end{array}$ \\
\hline 5 & $\begin{array}{l}\text { OD } \\
\text { OS }\end{array}$ & 67 & $\begin{array}{l}\text { ?trauma, ?AMD } \\
\quad \text { Mild AMD }\end{array}$ & $\begin{array}{l}\mathrm{CF} \\
6 / 5\end{array}$ & 8 weeks & $9 / 12$ & $6 / 24$ & $6 / 36$ & PED noted post-operatively \\
\hline 6 & $\begin{array}{l}\text { OD } \\
\text { OS }\end{array}$ & 55 & $\begin{array}{l}\text { Macroaneurysm } \\
\text { BRVO }\end{array}$ & $\begin{array}{l}1 / 60 \\
6 / 5\end{array}$ & 4 days & $3 / 12$ & $6 / 9$ & $6 / 9$ & \\
\hline 7 & $\begin{array}{l}\text { OD } \\
\text { OS }\end{array}$ & 80 & $\begin{array}{l}\text { AMD } \\
\text { SRNVM }\end{array}$ & $\begin{array}{l}\mathrm{HM} \\
6 / 60\end{array}$ & 5 days & $3 / 12$ & $6 / 36$ & $6 / 36$ & \\
\hline 8 & $\begin{array}{l}\text { OS } \\
\text { OD }\end{array}$ & 82 & $\begin{array}{l}\text { AMD } \\
\text { AMD }\end{array}$ & $\begin{array}{l}\mathrm{HM} \\
\mathrm{CF}\end{array}$ & 2 days & $6 / 12$ & $6 / 60$ & $\mathrm{HM}$ & $\begin{array}{l}\text { Lens opacity, re-bled } 6 / 52 \text {, ?occult } \\
\text { SRNVM }\end{array}$ \\
\hline 9 & $\begin{array}{l}\text { OD } \\
\text { OS }\end{array}$ & 75 & AMD & $\underset{6 / 6}{\mathrm{HM}}$ & 4 weeks & $12 / 12$ & $6 / 60$ & $6 / 60$ & \\
\hline 10 & $\begin{array}{l}\text { OD } \\
\text { OS }\end{array}$ & 78 & $\begin{array}{l}\text { AMD } \\
\text { AMD }\end{array}$ & $\begin{array}{l}\mathrm{HM} \\
\mathrm{C} / \mathrm{F}\end{array}$ & 4 days & $18 / 12$ & $6 / 9$ & $6 / 9$ & \\
\hline 11 & $\begin{array}{l}\text { OS } \\
\text { OD }\end{array}$ & 70 & AMD & $\underset{6 / 9}{\mathrm{HM}}$ & 4 days & $18 / 12$ & $6 / 24$ & $6 / 60$ & $\begin{array}{l}\text { SRNVM on FFA. Successful laser. } \\
\text { Re-bled later }\end{array}$ \\
\hline 12 & $\begin{array}{l}\text { OS } \\
\text { OD }\end{array}$ & 84 & $\begin{array}{l}\text { AMD } \\
\text { AMD }\end{array}$ & $\begin{array}{l}\mathrm{HM} \\
6 / 60\end{array}$ & 3 weeks & $12 / 12$ & $6 / 60$ & $3 / 60$ & $\begin{array}{l}\text { No SRNVM on FFA, re-bled } \\
\text { later, VA } \downarrow \text { ? occult }\end{array}$ \\
\hline 13 & $\begin{array}{l}\text { OS } \\
\text { OD }\end{array}$ & 73 & $\begin{array}{l}\text { AMD } \\
\text { AMD }\end{array}$ & $\begin{array}{c}6 / 24 \\
6 / 9\end{array}$ & 2 days & $18 / 12$ & $6 / 60$ & $6 / 60$ & $\begin{array}{l}\text { Per-op. per-foveal egression of blood, } \\
\text { ?iatrogenic foveal hole. SRNVM on } \\
\text { FFA untreatable }\end{array}$ \\
\hline 14 & $\begin{array}{l}\text { OS } \\
\text { OD }\end{array}$ & 74 & $\begin{array}{l}\text { AMD } \\
\text { AMD }\end{array}$ & $\begin{array}{l}\mathrm{HM} \\
\mathrm{PL}\end{array}$ & 2 days & $12 / 12$ & $6 / 36$ & $6 / 60$ & $\begin{array}{l}\text { Blood ++ in vitreous, hyphaema } \\
\uparrow I 0 P . \text { Inf. RD successfully treated }\end{array}$ \\
\hline 15 & $\begin{array}{l}\text { OD } \\
\text { OS }\end{array}$ & 85 & AMD & $\begin{array}{l}\mathrm{HM} \\
\mathrm{CF}\end{array}$ & 2 weeks & $12 / 12$ & $3 / 60$ & $3 / 60$ & \\
\hline
\end{tabular}

The first eye in each case is the eye which underwent treatment with tPA.

OD, right eye; OS, left eye; AMD, age-related macular degeneration; HM, hand movements; PED, pigment epithelial detachment; RD, retinal detachment; PVR, proliferative vitreoretinopathy; BRVO, branch retinal vein occulsion; SRNVM, subretinal neovascular membrane; FFA, fluorescein angiography; CF, counting fingers; PL, light perception.

Most commonly the symptoms had lasted for less than 1 week, but in 1 case (case 5) the symptoms had lasted for 8 weeks following a history of severe trauma to the head. No choroidal rupture was identified in this patient.

In all patients masking by subretinal blood was evident on the pre-operative fluorescein angiogram. Post-operatively a pigment epithelial detachment was identified in cases 3 and 5 and a subretinal neovascular membrane (SRNVM) in cases 11 and 13; we suspect that in cases 8 and 12 an occult membrane not identified on angiography may have caused subsequent subretinal bleeds some weeks following successful evacuation of the subretinal thrombus.

Visual acuity improved during the period of follow-up (range 3-18 months; mean 11, \pm 4.9 months) in all patients apart from cases 8 and 13 . The current post-operative visual acuity compared with the pre-operative visual acuity is represented graphically in Fig. 2. Case 8 developed a cataract, presumably from surgical or gas-related damage to the lens, in addition to a further subretinal bleed from presumed occult SRNVM. Case 13 originally had an eccentric SRNVM and subretinal blood and this was treated in a standard fashion. However, during injection of tPA, blood was seen to egress through the fovea and the possibility of precipitating a foveal hole by the 'ballooning of the macula' following injection must be borne in mind. This patient subsequently developed a SRNVM which was deemed untreatable, and visual acuity has deteriorated to 6/60. Most patients retained their initial improvement in visual acuity; in cases 5, 11, 12 and 14 the initial improvement deteriorated during the course of follow-up, but even this represented an improvement compared with pre-operative visual acuity.

Two patients developed inferior retinal detachments with proliferative vitreoretinopathy (cases 4 and 14). In case 4 , following membrane removal and scleral buckling, the retina flattened. A small inferior retinal hole was discovered but this was not related to the sclerostomy sites. In case 14 , a most dramatic subretinal bleed occurred filling most of the posterior pole and tracking inferiorly beyond the inferior arcades (Figs. 3, 4). A remarkably good evacuation of blood was obtained in this patient's only eye, but unfortunately an inferior retinal detachment developed 6 weeks later. This was felt to be due to a leaking retinotomy and was successfully treated with 


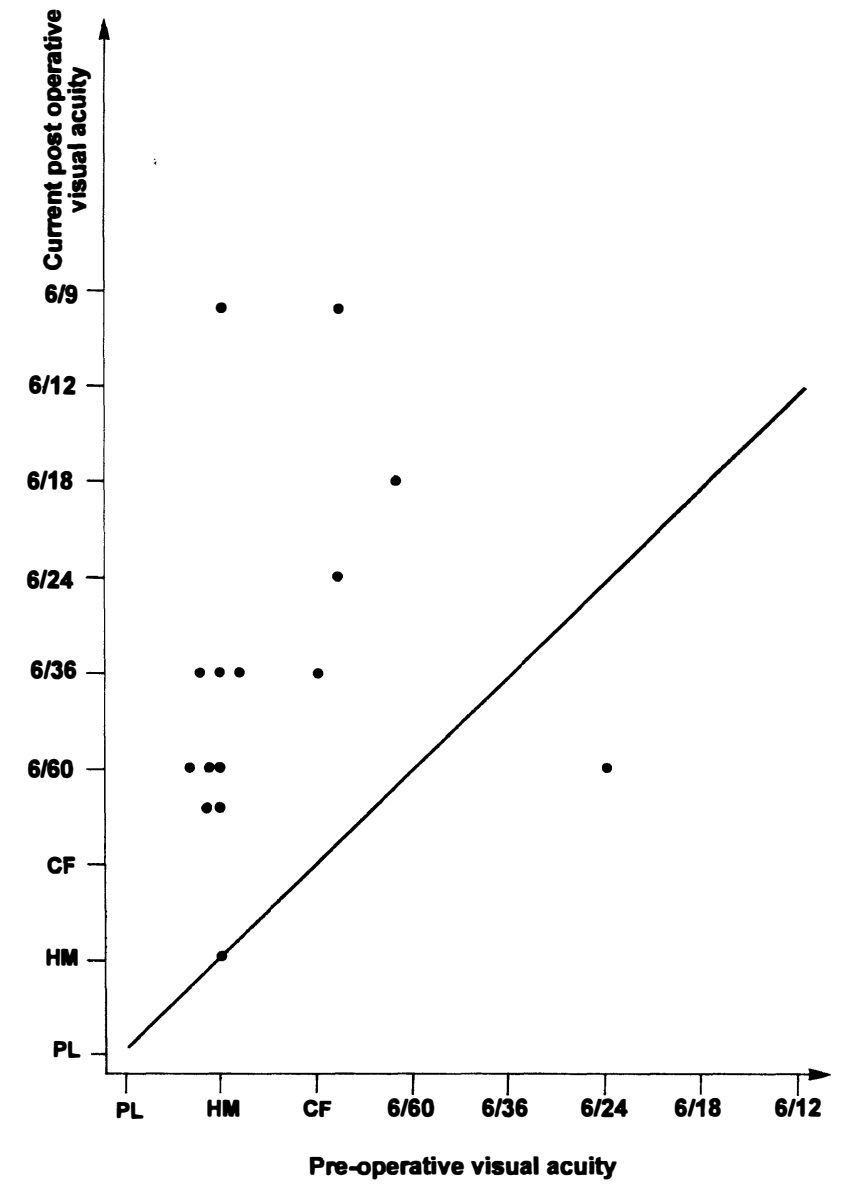

Fig. 2. Graph comparing current visual acuity with preoperative visual acuity in 15 patients over a period of follow-up (range 3-18 months; mean 11, \pm 4.9 months).

a vitrectomy, endolaser and internal tamponade. Prior to this not all retinotomies were lasered, but now we routinely endolaser all retinotomies.

Most commonly a moderate to good evacuation of thrombus was achieved peroperatively. There seemed to be a more satisfactory immediate evacuation of blood with the two-retinotomy technique than with a single-retinotomy technique. However, we noted that even in those cases where only a moderate evacuation had occurred peroperatively (cases $3,4,6$ and 8) there seemed to be a progressive dissolution of clot over the remaining few weeks.

Fundal photographs and fluorescein angiograms of selected cases treated by this method are shown in Figs. 3-9.

\section{DISCUSSION}

The poor visual prognosis following massive submacular haemorrhage ${ }^{1}$ is well known. The outer retinal damage and photoreceptor degeneration may result from the diffusion barrier formed by the clot, toxicity of iron released from red blood cells, and mechanical damage due to clot retraction and subsequent fibrosis. ${ }^{2,10}$ Surgical evacuation of thrombus has met with poor results ${ }^{3}$ and has led to the adoption of enzymatic dissolution of thrombus prior to aspiration of liquid blood via a small retinotomy in animal $^{5-7}$ and human studies. ${ }^{8,9}$ The enzymatic approach obviates the need to create a large retinotomy for introduction of forceps to remove the clot. Consequently there is reduced shearing damage to photoreceptors as the clot is not manually evacuated, and a reduced risk of retinal detachment and proliferative vitreoretinopathy.

Tissue plasminogen activator (tPA) is a serine protease which converts plasminogen to plasmin. The latter converts insoluble fibrin to its liquefied end-product. ${ }^{11}$ tPA has recently become available by recombinant DNA technology ${ }^{12}$ and has been widely used in post-vitrectomy fibrin dissolution, ${ }^{13}$ experimental retinal vein and artery occlusion ${ }^{14.15}$ and experimental hyphaema. ${ }^{16}$ Our results have been encouraging with this technique, which we adopted following the success reported in animal studies ${ }^{5-7}$ and the small human series published to date.,9

Early intervention is desirable since the presence of blood in the subretinal space for longer than 1 day can be toxic to the retina. ${ }^{2}$ However, this must be tempered by the tendency to promote rebleeding from vessels by tPA administration within 24 hours of an acute bleed ${ }^{17}$ and thus potentially from choroidal neovascularisation also. In practice the majority of our patients were treated between 3 and 7 days following an acute bleed and we saw no evidence of acute rebleeding. In addition, although early intervention is recommended, we were encouraged by the results with case 5 , who had had a submacular thrombus for nearly 8 weeks prior to referral to our centre. He did remarkably well and we feel it is reasonable to attempt removal of clot in cases as late as this if patients accept the possible risk/benefit ratio.

Our surgical approach differs somewhat from that in the other reports described in humans. We use a 30 gauge needle rather than a glass micropipette (50 $\mu \mathrm{m}){ }^{8}$ The needle produces a retinotomy of approximately $300 \mu \mathrm{m} .{ }^{7}$ However, even in this series using the micropipette the retinotomy was subsequently enlarged to $500-800 \mu \mathrm{m} .{ }^{8}$ Clearly the smaller size of retinotomy minimises the risk of proliferative vitreoretinopathy and retinal detachment; however, evacuation of small blood fragments may be compromised through too small a retinotomy, especially as the retina begins to flatten after the initial bulk of the thrombus is evacuated. The use of two retinotomies to allow through-and-through irrigation of clot may overcome this problem, but may accentuate shearing forces and currents under the retina. In practice we have usually gained satisfactory evacuation even through a one-retinotomy technique. The use of two retinotomies does, however, minimise the 'ballooning' of the macula following injection and the development of a foveal 


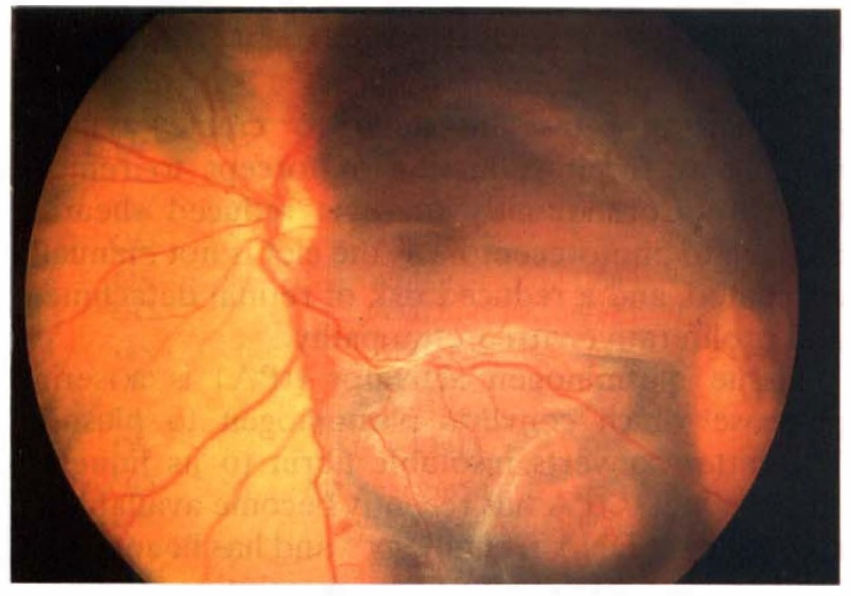

Fig. 3. Case 14. Enormous subretinal haemorrhage.

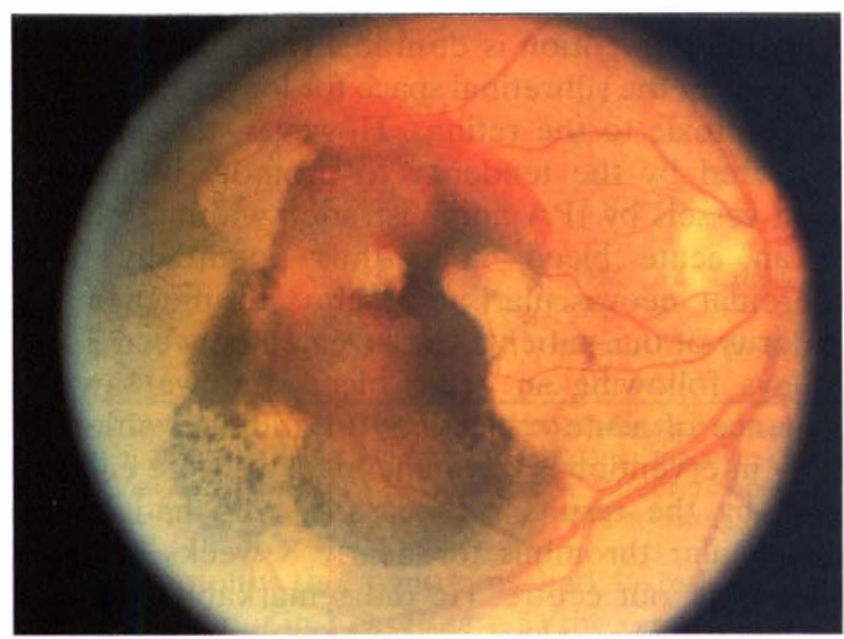

Fig. 5. Case 5. Submacular bleed of 8 weeks' duration.

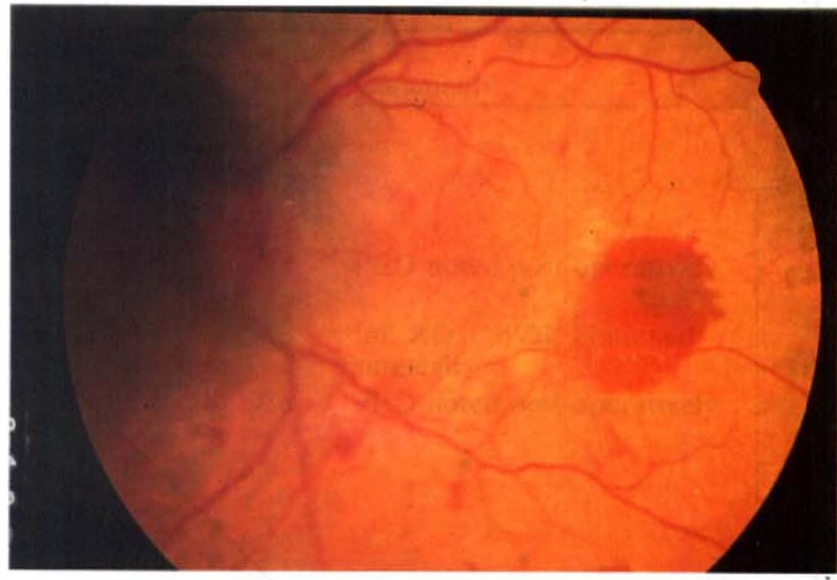

Fig. 4. Case 14. Appearance of posterior pole following treatment with TPA and evacuation of subretinal thrombus.

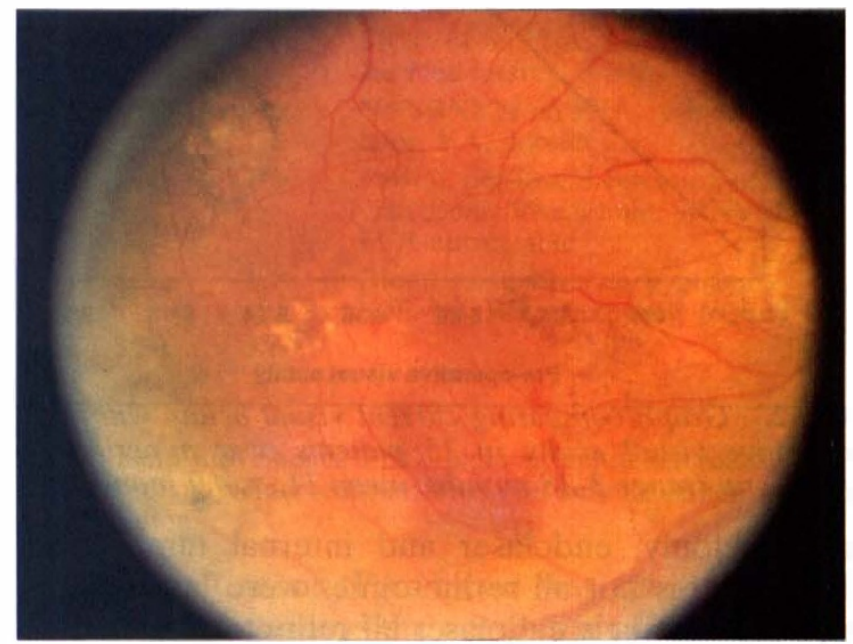

Fig. 6. Case 5. Appearance 1 week following evacuation of thrombus.

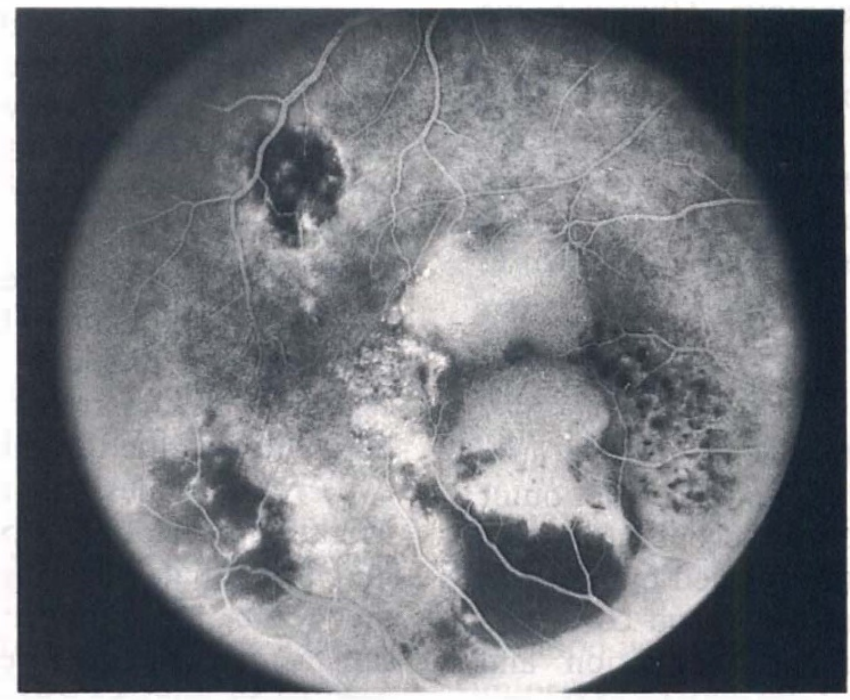

Fig. 7. Case 5. Fluorescein angiogram following evacuation of blood, demonstrating large pigment epithelial detachment. 


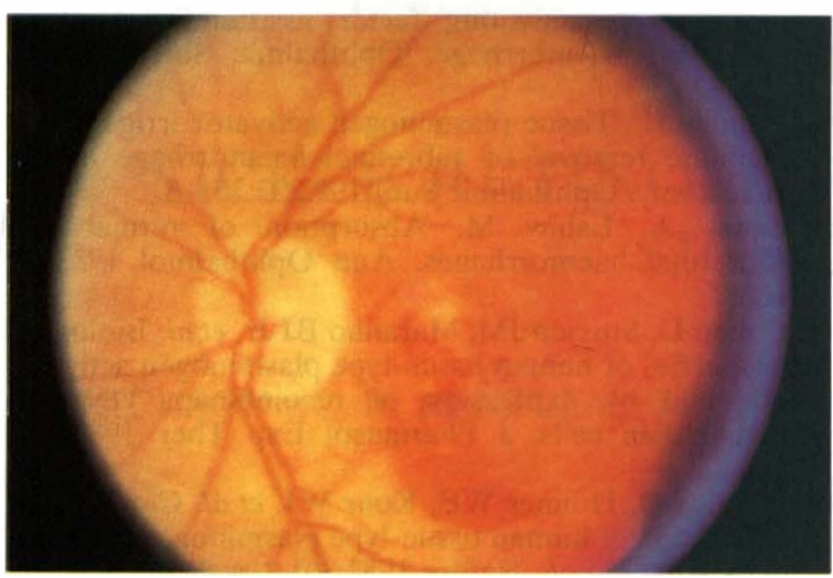

Fig. 8. Case 11. Appearance following evacuation of subretinal thrombus.

hole in one case (case 13) may have been prevented by a double retinotomy technique. Commercial 33 gauge cannulas and a double-barrelled subretinal injection aspiration system are now available and may also be used instead of a 30 gauge needle to deliver the tPA once a retinotomy has been created. However, we find our technique is simpler to perform, avoids any risk of subretinal shearing and suction forces, and is obviously less expensive.

We noted 5 cases where evacuation appeared only moderate or poor (cases 3, 4, 5, 6 and 8) after one injection. We injected a second time in these cases and in one case (case 5) achieved an excellent peroperative washout, but in the other 4 cases we subsequently still only evacuated a moderate amount of blood peroperatively. However, during the next few days there seemed to be a progressive dissolution of clot and in all 4 cases the flattening of the macula and area of clot resolved with excellent anatomical results. We suspect that there may be continuing enzymatic degradation of clot with enzyme adsorption either to thrombus or adjacent subretinal tissues that may prolong its action or perhaps facilitate endogenous enzymatic action. Consequently we are less disappointed by only moderate peroperative evacuations since the ultimate visual results appeared no worse in these cases than in those where an excellent peroperative washout was achieved (cases 1, 2, 5, 7, 9-15).

We employ a gas-fluid exchange following evacuation of clot since we find this facilitates further evacuation of blood via a gas compression of any remaining subretinal fluid in the posterior pole. The use of perfluorocarbon liquids has been suggested in a similar mode.We provide an intraocular tamponade to the retinotomy with a nonexpansile concentration of $\mathrm{SF}_{6}$, which may be unnecessary and possibly promote lens opacities in phakic eyes. The use of smaller cannulas and micropipette $(50-65 \mu \mathrm{m})$ irrigation and aspiration techniques under stereotactic control ${ }^{7}$ may obviate

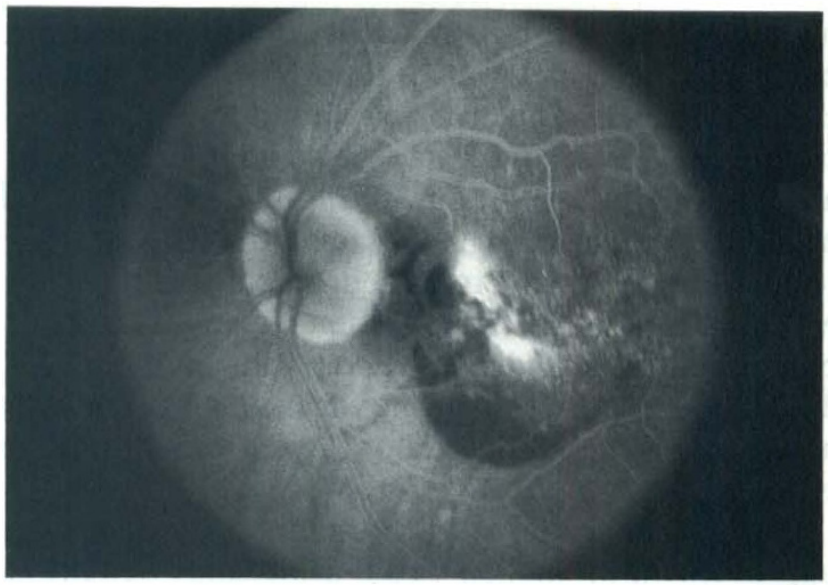

Fig. 9. Case 11. Fluorescein angiogram reveals a subretinal neovascular membrane. This was initially treated successfully but later re-bled.

the need for endolaser and internal tamponade of such very small retinotomies, but with present techniques we feel more assured by adoption of these adjuncts.

It was of interest that we discovered demonstrable SRNVMs in only 2 cases (cases 11 and 13) on fluorescein angiography subsequent to thrombolysis, although we suspect occult neovascularisation may have occurred in cases 8 and 12 to promote rebleeding. Whether washout of angiogenetic factors or factors that may encourage maturation of an SRNVM occurs with this technique are possibilities. Alternatively a surgical amputation of a neovascular complex may have occurred or bleeding may have been promoted by an RPE tear.

In addition, then, if occult choroidal neovascularisation does ensue, the role of indocyanine green videoangiography after thrombolysis to identify ${ }^{18}$ and facilitate treatment of occult SRNVM remains a future possibility, ${ }^{19}$ as does peroperative fluorescein angioscopy and endolaser for demonstrable SRNVMs. ${ }^{20}$

We were encouraged by results of our initial clinical investigation with tPA assisted thrombolysis. Retinal toxicity ${ }^{6}$ and rebleeding ${ }^{17}$ is unlikely with total doses of $50 \mu \mathrm{g}$ and in the absence of segmented vessels respectively. Other possible complications include promotion of SRNVMs by endolaser photocoagulation and rebleeding from an established SRNVM or macroaneurysm. In practice, ensuring a delay of 1-2 days prior to treatment may avoid this latter complication. Obviously the hazards of photocoagulation to retinotomies must be borne in mind and the development of techniques using small retinotomies ${ }^{7}$ may obviate the necessity for this and also reduce the risk of retinal detachment and proliferative vitreoretinopathy.

The procedure is not without complication and the development of a cataract in one patient (case 8) and retinal detachments in two others (cases 4 and 14) 
highlight this. The possibility of tPA promoting the latter has been previously reported. ${ }^{21}$ As with all clinical investigation a proper randomised clinical trial is the best method to assess clinical efficacy of any treatment. However, the poor prognosis of untreated submacular bleeds and the encouraging results obtained with treatment make it difficult to withhold treatment. Indeed when we counselled our patients all expressed a desire to try the method. This desire was even more pronounced in patients who had lost vision in the fellow eye from a similar process.

Even those patients who do not experience an improvement in Snellen visual acuity may benefit in low visual acuity if subsequent scotoma size is reduced following treatment. Prospective clinical trials addressing these matters would be of interest as life expectancy increases.

\section{REFERENCES}

1. Bennett SR, Folk JC, Blodi CF, Klugman M. Factors prognostic of visual outcome in patients with subretinal haemorrhage. Am J Ophthalmol 1990;109:33.

2. Glatt $H$, Machemer R. Experimental subretinal haemorrhage in rabbits. Am J Ophthalmol 1982;94:762.

3. Vander JF, Federman JL, Greven C, et al. Surgical removal of massive subretinal haemorrhage associated with age related macular degeneration. Ophthalmology 1991;98:23-7.

4. Toth CA, Morse LS, Hjelmeland LM, et al. Fibrin directs early retinal damage after experimental subretinal haemorrhage. Arch Ophthalmol 1991;109:723-9.

5. Johnson MW, Olsen KR, Hernandez E. Tissue plasminogen activator thrombolysis during surgical evacuation of experimental subretinal haemorrhage. Ophthalmology 1992;99:515-21.

6. Lewis H, Resnick SC, Flannery JG, Straatsma BR. Tissue plasminogen activator treatment of experimental subretinal haemorrhage. Am J Ophthalmol 1991; 111:197-204.

7. Toth CA, Benner JD, Hjelmeland LM, et al. Ultramicrosurgical removal of subretinal haemorrhage in cats. Am J Ophthalmol 1992;113:175-82.

8. Peyman GA, Nelson NC, Altukri W, et al. Tissue plasminogen activating factor assisted removal of subretinal haemorrhage. Ophthalmic Surg 1991;22: 575-82.

9. Vander JF. Tissue plasminogen activator irrigation to facilitate removal of subretinal haemorrhage during vitrectomy. Ophthalmic Surg 1992;23:361-3.

10. Gilles A, Lahav M. Absorption of retinal and subretinal haemorrhages. Ann Ophthalmol 1983;15: 1068.

11. Collen D, Stussen JM, Marafino BJ Jr, et al. Biological properties of human tissue-type plasminogen activator obtained by expression of recombinant DNA in mammalian cells. J Pharmacol Exp Ther 1984;231: 146-52.

12. Pennica D, Holmes WE, Kohr WJ, et al. Cloning and expression of human tissue-type plasminogen activator cDNA in E. coli. Nature 1983;301:214-21.

13. Williams GA, Lambrou FH, Jaffe GJ, et al. Treatment of post-vitrectomy fibrin formation with intraocular tissue plasminogen activator. Arch Ophthalmol 1988; 106:1055-8.

14. Oncel M, Peyman GA, Koobebi B. Tissue plasminogen activator in the treatment of experimental retinal vein occlusion. Retina 1989;9:1.

15. Vine AK, Maguire PT, Martoryi C, Kincaid MC. Recombinant tissue plasminogen activator to lyse experimentally induced retinal arterial thrombi. Am J Ophthalmol 1988;105:266.

16. Lambrou FH, Snyder RW, Williams GA. Use of tissue plasminogen activator in experimental hyphaema. Arch Ophthalmol 1987;105:995-7.

17. Sternberg P Jr, Aguilar HE, Drews C, et al. The effect of tissue plasminogen activator on retinal bleeding. Arch Ophthalmol 1990;108:720-2.

18. Destro M, Puliafito CA. Indocyanine green videoangiography of choroidal neovascularisation. Ophthalmology 1989;96:846-53.

19. Balles MW, Puliafito CA, Kliman GH, et al. Indocyanine green dye enhanced diode laser photocoagulation of subretinal neovascular membranes. Invest Ophthalmol Vis Sci 1990;31(ARVO Suppl):282.

20. Avery RL, Hickingbotham D, Jaffe G, De Juan E. Intraoperative fluorescein angioscopy in subretinal surgery [letter]. Arch Ophthalmol 1992;110:1518-9.

21. Johnson RN, Olsen KR, Hernandez E. Intravitreal tissue plasminogen activator treatment of experimental vitreous haemorrhage. Arch Ophthalmol 1989;107: 891-4. 